\title{
Characteristics of organizational culture and climate in knowledge-intensive organisations
}

\begin{abstract}
The article focuses on organizational culture and climate in knowledge-intensive organizations, aiming to identify the specific values and features of climate for each sector.The sample of organizations included organizations from five sectors: higher education, banking and financial, research and development, IT and marketing-advertising. The qualitative design of research included near 80 in-depth interviews with employees and managers. The results showed that climate was based on various characteristics: human relations and friendship in small marketing-advertising agencies and IT companies, competition in large advertising companies. In the research development sector, the climate was based on achieving goals in the private area of the sector ( in higher education as well), while in the public areat of the sector it was based on freedom and creativity. The climate in the banking sector was very different, being based on discipline and obeying rules. From the point of view of the organizational culture, all the interviewed employees of the advertising, IT and banking sector experienced, inside the company, the presence of certain forms of organizational culture. Only half of the interviewees from the higher education sector admit to the presence of an organizational culture in their institution while in the public funded research-development sector, employees reportedly did not experience visible manifestations of any type of organizational culture.
\end{abstract}

Keywords: organizational culture, organizational climate, knowledge-intensive services.

\section{Organizational culture and climate - the conceptual framework}

Schein $(1984$, p. 3) defined organizational culture as being "the pattern of basic assumptions that a given group has invented, discovered, or developed in learning to cope with its problems of external adaptation and internal integration, and that have worked enough to be considered valid, and therefore, to be taught to new members as the correct way to perceive, think and feel in relation to those problems". Thus, organizational culture is a frame of beliefs, opinions, values, that serve for the orientation of behavior for both the older members of an organization and for the new members. As Schein underlined (1990, p. 15), culture is always dynamic and covers all aspects of human functioning, the methods recommended for studying this pattern of basic assumptions (which in most cases are unconscious) are the interview and the observation. Later, Schein identified (1990, p. 110) the different perspectives that contributed to the foundation of the concept: the survey research (culture as a property of groups that can be measured using questionnaires), the analytical descriptive perspective (culture as a concept for which empirical measures can be developed by breaking down the

* National University of Political Studies and Public Administration, cristina.leovaridis@comunicare.ro.

${ }^{* *}$ National University of Political Studies and Public Administration, diana.cismaru@comunicare.ro. 
concept into smaller units), ethnographic (concepts from sociology and anthropology applied to the study of organizations), historical, clinical descriptive (organizational development). In the same paper, Schein characterizes the three levels of manifestation of organizational culture (1990, p. 111): visible artifacts, values and underlying assumptions. Soon after Schein's definition, several scholars (Bromley, 1993, 2001; Dutton, Dukerich \& Harquail, 1994; Hatch \& Schulz, 1997; Balmer, 2000; Dowling, 2001; Whetten \& Mackey, 2002) emphasized the difference and the reciprocal conditioning between organizational culture and other related concepts, such as climate, identity and image.

For the majority of authors, there were clear differences in formation, border and organizational function of each concept. Thus, organizational identity refers to "what members perceive, feel and think about their organizations" (Hatch \& Schultz, 1997, p. 357). Also, Ravasi and Schultz (2006, p. 437) observed that culture tends to be tacit and autonomous, incorporated in shared practices and norms, identity is rational and consciously self-reflexive.

On the other hand, Bromley (2001, p.317) defines the organizational image as the "internal collective state that is set at the basis of communication efforts (succeeded or not) in view of external presentation". Also, image is formed by the elements designed by organizational decision actors as central, distinct and stable in the perception of stakeholders (Whetten \& Mackey, 2002, p. 401). Dowling (2004, p. 21) made the distinction between image and identity observing that "image is the perception of a person about the organization, while identity refers to the attributes used for describing an organization".

The distinction between organizational culture and organizational climate is more difficult. Denison observed (1996, p. 620) that in some papers these two concepts are confounded with each other, being sometimes defined in the same way. In the early approach, climate was defined as the perceptual measurement of organizational attributes or as a multiple measurement of organizational measurement, combining perceptual and more objective attributes (Hellriegel and Slocum, 1974). The central issue of whether climate is a shared perception or a shared set of conditions is still a basic issue in debate (Denison, 1996, pp. 621-624). The cultural approach moves the emphasis from the individual perceptions as a source of climate formation to the interaction of organization's members (Moran and Volkwein, 1992, p. 35). In this approach, climate is defined as "a relatively enduring characteristics of an organization which distinguishes it from other organizations and (1) embodies members collective perceptions about their organizations with respect to such dimensions as autonomy, trust, cohesiveness, support, recognition, innovation and fairness; (b) is produced by members' interactions; (c) serves as a basis for interpreting situations; (d) reflects the prevalent norms, values, and attitudes of organization's culture; (e) acts as a source of influence for shaping behaviors" (Moran and Volkwein, 1992, p. 20). Although it provides an operational model for the analysis of climate in various organizational settings (a model that will be used in this paper), this definition might be confused with the definition of the organizational culture. In the view of the two previously cited authors, climate refers more to attitude and values (it is conscious and more visible) and "is more shallow, it forms more quickly and alters more rapidly" (Moran and Volkwein, 1992, p. 39).

Building on the interactive and cultural approach of climate, a specific concept has been introduced by Nonaka, Krogh and Voelpel (2006, p. 1185), defining " $B a$ " as a shared space for emerging relationships, a type of climate that enables knowledge conversion. The term is significant mainly in the knowledge-intensive organizations and might be considered as a distinctive factor in stimulating performance. A legitimate question that could be raised refers 
to whether this type of climate may exist in a totally different culture (as the Romanian culture is).

In what concerns the relations between concepts, that is culture, identity and image being interdependent (Hatch \& Schultz, 1997, p, 360), the scholarly perspectives on factors and types of interdependence are different among authors.

Dutton, Dukerich \& Harquail (1994, p. 260) demonstrated that the attachment of employees to the organization is influenced by the individual image developed by them: "if images offer continuity, differentiation or positive evaluations, the feeling for the organization becomes strong in the process of identification". Accordingly, the organizational image becomes an important agent of identification, stimulating certain behaviours to some of the members.

Hatch and Schulz (1997, p. 360) defined organizational culture as "a symbolic context within which interpretations of organizational identity are formed and intentions to influence organizational image are formulated". The two authors appreciate that cultural artifacts are used in the symbolic process of image building and that image is translated in various contexts by using cultural interpretations of individuals. Hatch \& Schultz (1997, p. 358) observed that identity is formed as a consequence of interactions between an organization's members and as an effect of managerial influence upon the social context of the organization. Also, while the organizational border with the external environment diminishes, identity is more and more influenced and influences, at its turn, the organizational image. The authors observe that image may influence identity as well, especially when the organization's members find themselves in the external perceptions or when management involves in the strategic building of organizational image.

Ravasi and Schultz (2006) demonstrate in their study the role of organizational culture in driving identity dynamics, in the process of responding to identity-threatening changes in the environment. In the authors' view, organizational culture acts as a "platform for sensegiving" (p. 452) enabling the retrospective rationalization, the preservation of self and continuity.

\section{Organizational culture in knowledge-intensive organizations}

Knowledge-intensive companies are defined as companies depending on "the production, usage and originality of their knowledge fund" (Donaldson, 2001, p.957), "the attribute of knowledge-intensive can be applied to companies where knowledge is more important than any other inputs, and human capital is dominant, as opposed to the financial or physical one" (Swart, Kinnie, 2003, p.61), a key feature of this type of firms being their capacity to solve complex issues by developing creative and innovative solutions. This type of organization changes essential aspects regarding the managerial dimension and that of human resources (Leovaridis, 2008, p. 258): for instance, from using specific traditional resources - land, energy etc. - to the knowledge resources; from mass management to a more personalized one; from respecting job requirements to negotiating competences etc.

The category of knowledge-intensive companies (which "sell" knowledge) comprises an ample and heterogeneous series of companies: consultancy companies from various workfields (financial, legal, accounting, and management), media companies, advertising agencies, research and education institutions, software companies etc. The main features of knowledgeintensive companies - features that differentiate them from other firms- according to the nature of their work and the manner of their organization and leadership, are (Alvesson, 2004, 
pp. 21, 38-39): highly qualified employees performing knowledge-related activities, using symbolic and intellectual abilities in their work; a high degree of autonomy and flat organizational hierarchies; the usage of flexible, adaptable and ad hoc organizational forms; the need of extended communication for coordination and problem solving, because of a high level of ambiguity; a consumer-oriented approach, especially in the professional services firms; information and power asymmetry owing to the expert's position (often working in favor of the profession and to the consumer's detriment); a subjective and uncertain evaluation of the work results' quality. To the above listed seven features of the knowledge-intensive organizations, one can add another one (Alvesson, 2004, pp. 237-238, 189): knowledge-intensive companies are places where one can adjust identity - while the management is involved in adjusting identities, employees accepting the prescribed identity is not sufficient enough, and the intense symbolic work of developing, maintaining and changing identities is an essential part of the managerial activity; the employees in the knowledge field become "identity workers", as the manager becomes an adjustor of them. Identity has a special relevance to knowledge-intensive organizations, as it is important that management influences it: in order to gain control upon the organization; in order to create an internal foundation for image management; in order to ensure the loyalty of the employees by avoiding their leaving; in order to counter uncertainty and build confidence and self-esteem at the workplace.

Identity has thus implications on organizational control, loyalty, image management, as well as on the psychological aspects deriving from working in a fragmentary and ambiguous environment. It is important for the organization's management to adjust and model identities in the absence of efficient mechanisms of hierarchic control. Aspects such as sharing knowledge and consumer-oriented approaches within professional services firms depend on the manner in which employees define themselves. When hierarchic means can no longer prescribe in detail the approapriate behavior, because of the complexity and ambiguity of work tasks, self-image and the groups through which employees define themselves have a greater significance. Identity goes beyond culture, indicating the manner in which people define themselves, involving personal and individual aspects, while organizational culture refers to socially-shared meanings and ideas. Many cultural aspects have consequences on the building of identity and viceversa.

Ambiguity, uncertainty and lack of determination can be a "natural" state of things in the knowledge-intensive companies. Mats Alvesson stated that "ambiguities involved in the notion of knowledge, in what employees do in knowledge-creative companies and the difficulties in evaluating their activities lead to the conclusion that arbitrariness and vulnerability characterize many of the knowledge-intensive organizations and their employees. In this context, the employees of the field need to live with the ambiguity and even capitalize on it" (2001, p. 882). But such contexts characterized by ambiguity offer opportunities for the construction of positive identities, both individual ones (such as that of a "scientific expert") and organizational (such as that of "innovative company") and then require activities that would validate these identities.

Some time ago, great confidence was placed on the idea that organizations have unitary cultures and that top managers are the architects behind them, but this idea gradually lost credibility. Two alternatives appeared in exchange, both critical and complementary. One highlights context and daily life as generating severe variations inside organizations - it is claimed that, for instance, the specific tasks of work teams influence more their values rather than the company's global business. One can add that the social interaction and identifica- 
tion, which often overlap work conditions; work situation and group interaction lead to the existence of local cultures within organizations, which are different and sometimes opposite to the culture instituted by the management. Another criticism refers to the fact that employees, apart from belonging to the organization, belong also to other groups such as gender, profession, ethnic community etc., from which they extract certain ideas and values, different from the ones of the organization. This reduces the possibility of management to impose its own values and ideas to the employees (Alvesson, 2002, p. 167).

Naturally, a question arises: "In what way can a strong culture, based on the acceptance of ambiguity (in rules, power relations, organizational practices and routines), promote the development of a loyal and efficient workforce and of flexible work projects?'. Such culture, often coupled with a corporatist identity based on elitism, should help in maximizing loyalty and minimizing tensions between control and autonomy. A culture aware of ambiguity may use a form of normative control in which experts act freely, but at the same time participate, of their own will, to the drawing of regulations of their own autonomy (and creating conditions that would ensure their own control). It acts as a powerful form of normative control leading to the appearance of high levels of loyalty and work attachment among "autonomous" employees. Solving the managerial dilemma of ensuring a balance between autonomy and control leads to a form of control based on normative and cultural processes, rather than on hierarchy and structure.

Within knowledge-intensive companies, the minimum control needed for the development of common activities should be founded on professionalism and the development of strong cultural values, reached by consensus. The tensions inherent to the knowledge-related activity should be mediated through a strong organizational culture "which would promote self-discipline (responsible autonomy) and the integration of the individual in the organizational environment (an environment characterized by low levels of formality) so that employees would have confidence in the company and work in its best interest" (Alvesson, 2002, p. 4).

The policies of these companies in the field of human resources encourage the behavior of an "organizational citizen", with the aim of building a cohesive organizational culture centered on innovation; the human resources departments of these organizations have an essential role in the knowledge economy by introducing organizational policies which are centered on the stimulation of employees creating knowledge. The difficulty resides in ensuring the organizational attachment from the employees for whom the profession comes first; successful organizations overcome this difficulty by creating a working environment which quenches employees" "knowledge thirst", by offering access to intra- and inter-organizational cooperation networks, among professionals who are treated as "sources of potential" and not as costs that need to be cut or means that need to be controlled (Thite, 2004, pp. 28-30).

\section{Research methodology}

The empirical research of this paper is part of a larger and complex research, aiming at a comparative study of the work conditions of Romanian highly-qualified employees in five sectors of knowledge-intensive services, specific to the knowledge economy: IT\&C, research\&development, higher-education, marketing-advertising and banking, as these are perceived both from the point of view of the employees as well as the managers in these fields. 
The initial research ${ }^{1}$ intended to collect information regarding several aspects (Leovaridis, 2013, pp. 190-199, 312-370): employees' health problems related to the workplace, working time (including atypical schedule such as evenings, nights, weekends, shifts), work complexity and intensity, professional development possibilities, workplace autonomy levels and the possibility to influence one's work, culture and communication, decision-making and leadership styles both within the team and the organization, motivational means, work-life balance, professional satisfaction and social dialogue, measures suggested by employees and measures taken by employers in order to improve working conditions.

Based on this initial research, the present article will focus only on the aspect of interest to this paper, more precisely on organizational culture and climate. The interview-guide questions regarding these aspects were: "How does the organizational culture of your company manifest (are there certain values, norms, written or non-written regulations, specific symbols, myths/stories on the history/founders of the company, are there anniversaries organized to celebrate the company, employees, Christmas, the awarding of employees etc?"(for the first aspect) and "Do your co-workers help and support you? What about your hierarchical superior? Is there cooperation, help and a positive atmosphere among colleagues, do you feel part of a groups or do you work in isolation from the other co-workers?", "Is your hierachical supervisor open / available to listen to your work-related issues?", "How would you characterize the climate within the company (by highlighting competition, promotion of exceptional individuals or human relations, friendship, teamwork; the achievement of company objectives or employee satisfaction; subordination and respect for regulations or autonomy and employee freedom; compliance and discipline or initiative, creativity; risk/defensive attitude etc.)?" (for the second aspect).

The surveyed group was represented by approximately 80 respondents, consisting of 12-15 highly qualified employees without leadership positions and 2-3 managers of each of the five sectors mentioned before. We have conducted a qualitative research, made up of in-depth, faceto-face interviews with both the employees without any leadership positions and with persons with leadership positions from the above enumerated five sectors of knowledge-intensive services. Each interview with the employees and managers lasted 50-60 minutes. The reason for using this qualitative research is the very nature of the subject submitted for research: only such a method can help the research to obtain the details of complex and intangible aspects such as organizational culture and climate within companies of the knowledge society related sectors. As a technique associated with this method, the two authors have used the semistructured interview, which is centered on the perspective that respondents have on the discussed matter, provides the opportunity of a complex, in-depth interpretation of the phenomenon, leading to the identification of new research directions which has not iniatially been taken into account by the researchers.

When choosing the respondents' organizations, we have chosen various ones, from the point of view of the sources of economic capital (state and private, Romanian and multinational), company dimensions (small, medium, large) and specialization. These aspects, corroborated with the subjects' opinions, will offer an overall image of the respective economic sector. 


\section{Research results}

The table that summarizes the demographic characteristics of the people interviewed (age, gender, position in the organization, whether employee or manager) can be found in Annex 1. The conclusions resulted from the empirical research shall be supported by quotations from the interviewees, that can be found in Annex 2 (employees from the IT\&C sector will be abbreviated as IT.E., research\&development employees - R.E., those in higher education sector as E.E, those in the advertising-marketing sector as A.E. and finally, those in the banking and financial sector - B.E.; the same is valid for the managers: IT\&C managers - IT.M., research-development managers as R.M, managers in higher education - E.M., advertising managers - A.M. and the managers in banking and financial sector-B.M.).

\subsection{Organizational culture and climate in the IT\&C sector}

Regarding the existence of team spirit as well as the presence of a united team, for a large majority of the respondents (13 out of 15), help and cooperation are present within the team. There are, howeve, $r$ three exceptions: one of the respondents claims there is weak communication with the co-workers from abroad while the other two remember the ongoing competition between co-workers and short deadlines preventing a positive attitude from installing within the team. Regarding the understanding and help received from the hierarchic superior, two thirds are content with the attitude of their superior, but there are also some who expressed in an explicit manner their discontent towards the relationship with the hierarchic superior.

From the point of view of the organizational culture, all respondents (with only two exceptions) felt the existence of some forms of organizational culture within the company, represented by: Christmas parties, birthday parties especially inside the teams, teambuildings organized by the company, company logos and slogan, bonuses and symbolic awards for the employees having considerable results in their work, company values and history, company anniversaries, written and unwritten internal behavior rules.

According to the answers provided by the majority of the interviewed employees, organizational climate is based on teamwork, human relations, employee satisfaction, being accompanied by achieving company goals, compliance, discipline, obeying rules. Only one employee referred to the emphasis being placed on showing initiative, creativity and autonomy within his organization.

From the managers' point of view, they confirm the opinions expressed by their employees. Regarding organizational culture, all three companies display elements of its presence differentiated only by the company incomes: only Christmas parties in the small Romanian company, along with "organizing company anniversaries and awarding employees" added within the larger multinational company, while in the medium-sized multinational company, employees in the same department enjoy trips abroad. In managers' opinion, the organizational climate is based on obeying rules and accomplishing goals, for both multinational companies; the answers provided by their managers, on subordination and formality, confirm once again the ideas already expressed by the sector's employees. In the small Romanian company, the organizational climate is dominated by teamwork and encouraging creativity, even if discipline is also an important element. 


\subsection{Organizational culture and climate in the research-development sector}

With regard to the existence of cooperation among co-workers and a positive atmosphere within the team, the majority of respondents without any leadership positions (three quarters) showed that such support and cooperation is present within the team. As far as a quarter of the respondents are concerned, envy among the co-workers is often mentioned, as well as the fact that they work mostly alone, individually, without being part of a team.

Regarding the help and understanding received from the hierarchic superior,a half of the respondents were content with the attitude of their manager, who offers them support. The remaining half expressed their discontent on their relationship with the superior, who either does not listen or help them, or supports them "occassionally" / "apparently".

From the point of view of organizational culture, the majority of the respondents did not feel the existence of some forms of organizational culture manifesting within the institute. Of the few who claim that there are some manifestations of organizational culture, they only refer to employee and Christmas celebrations, as well as the presence of written regulations, but at the same time, they do admit that this is a poorly structured organizational culture.

According to the answers of more than a half of the interviewees without any leadership positions, the organizational climate is based on the following: in the two private institutions - on achieving the institution's goals; in the public ones - on teamwork co-existing with competition among researchers (sometimes accompanied by envy), on employee freedom, encouraging initiative spirit and creativity at the same time with fulfilling the institute's goals.

Once again, the managers' answers are similar to those of the employees regarding the perception of organizational culture and climate and the relationships between co-workers (the envy that can be present sometimes between co-workers has also been noticed by the institutes' management). Regarding the organizational knowledge, according to the managers, both institutes lack forms of organizational culture, with the exception of the regulations established by the "mother company" - the Romanian Academy. According to the managers, for both organizations, the organizational climate is based not only on the competition generated by promotion established by very strict criteria, but also on teamwork, since the research is, by excellency, a field of work requiring teamwork. Moreover, the climate is characterized both by achieving goals, as long as every researcher has a yearly working plan, and by freedom of action, initiative and creativity which are fundamental in the research activity. The second interviewed manager reminds of the "roughness existing among people", but "the small conflicts that have emerged have been solved by tete-a-tete discussions so that tension diminished and did not affect the local climate of the organization".

\subsection{The organizational culture and climate in the higher education sector}

With regard to whether there is support within the group, only a half of the respondents without any leadership admitted to have experienced such support and cooperation from their co-workers. As far as the other half is concerned, there are mentions on help received only from some of the co-workers, partially or not at all. A majority of respondents consider that the atmosphere of the group is a positive one, generally a cooperation-oriented one, and they claim to feel as part of a team. As far as the understanding and help received from the hierarchic superior, the majority of respondents showed to be relatively content with the attitude of their superior, some claiming that they are listened to, "but the situation doesn't change", 
or they received help from the manager coordinating their activity, but he/she does not listen to their problems etc.

From the point of view of the organizational culture and its forms of manifestation, approximately a half of the respondents experienced some form or another of the organizational culture, consisting mainly of employee anniversaries, Christmas parties, term parties, myths on the founding of the university.

According to the answers of more than a half of the interviewees without any leadership attributions, the climate in the organizations they come from is based on: teamwork within the research projects, achieving the institution's goals, "sometimes by making sacrifices regarding employees' satisfaction"; encouraging creativity and initiative; competition among co-workers; respect for hierarchy; discipline.

From the managers' point of view, with regard to the organizational culture, while the second organization does not have a certain organizational culture, in the first one, this type of culture manifests through values (unity), the existence of a founding hero of the university, myths on the university's/faculty's first years. In addition to that there are visible differences between the two higher-education institutions with regard to the organizational climate. In the case of the first organization, the climate is based on competition, achieving a career, accomplishing goals, competence, market and student requests adaptability and secondarily, there are teamwork (within projects) and autonomy. The second interviewed manager mentioned the fact that within his organization, climate is based on "interest in the educational act". The perception that employees have is in agreement with that expressed by the interviewed managers.

\subsection{Organizational culture and climate in the advertising-marketing sector}

In what concerns the existence of teamwork spirit and support from co-workers and the hierarchic superior, two-thirds (11) of the responding employees claim there is cooperation and help within the team, and the lack of this atmosphere of cooperation is more likely an exception, mentioned by only 3 respondents. As far as the understanding received from their hierarchic superior is concerned, almost half ( 7 participants) of the respondents were content with the attitude of their superior, who listens to them and offers them the necessary support; on the other hand, only an employee, of a multinational company, expressed his obvious discontent ("the creative director was especially tough and authoritative").

From the point of view of organizational culture, all responding employees (with one exception) felt the existence within the company of some forms of organizational culture, represented in the Romanian financial capital-infused agencies by: going out with the co-workers, especially for beer, Christmas and birthday parties, company organized teambuilding, company logos, decorated offices, symbols, symbolic awards for the employees having the best results in their work, company values, internal regulations, common language and humor inside the company, which outsiders cannot access, rituals, playing sports together. In multinational companies, the organizational culture emphasis lies on the myths regarding the founders of the multinational network.

According to the answers of the interviewed employees, the organization's climate is based on human relationships, friendship, teamwork, employee freedom in most small organizations with Romanian capital, naturally by respecting a set of "minimal rules of common sense"; but also on competition and fulfilling goals within the multinational companies, where employee happiness is seen as a consequence of fulfilling goals. 
As far as the interviewed managers are concerned, regarding organizational culture, their opinions confirm those of the employees. Within the two multinational companies whose managers we interviewed, this gravitates around the company founder; on a local level, the large company organizes Christmas parties, anniversaries for employees and the agency's birthday date, awards for considerable employee results, teambuildings; within the small multinational agency there are also rules and regulations. Within the Romanian company, since it is rather young, an organizational culture has not been formed yet, "it is continuously being developed".

According to the managers who participated in the interviews, organizational culture within the agencies they manage is based on autonomy, teamwork, friendship and creativity encouragement - this is valid for all three agencies, despite dimensions and the source of financial capital (despite the tension created by short deadlines, in the multinational companies); additionally, the stimulation of competition that employees mentioned before is not to be found here.

\subsection{Organizational culture and climate in the financial-banking sector}

With regard to the existence of team spirit and support from the co-workers, as well as the presence of a positive atmosphere, depicting a united team, the majority of the respondent employees stated that there is cooperation and help among the team.

Regarding the understanding and help received from their hierarchic superior, the majority of the workers showed content on the attitude of their superior, whereas two claimed to be dissatisfied on the attitude of their hierarchic superior, who is either too busy to listen to them, or listens to them but fails to help them in solving their problems.

From the point of view of the organizational culture, all interviewed employees felt the presence within the company of some forms of organizational culture, represented firstly through values, norms, rules and regulations. Adding to that, there are also, but more rarely, Christmas parties, employee birthday anniversaries, awarding employees for special results, company awarding ceremonies, even company symbols.

According to the answers of over a half of the interviewees without any leadership role, the organizational climate is based on: compliance, discipline, obeying rules; an emphasis on competition, promoting individuals, achieving goals, but also accompanied by friendships among co-workers and teamwork. None of the employees referred to an emphasis on showing creativity and autonomy inside his/her organization, or the emphasis laid only on human relations and employee satisfaction.

Once again, employee opinions are convergent with those of the managers. Regarding organizational culture, both companies display well defined elements of the concept, while the differences that could appear are owed to the policy of the mother company - there are company and employee award ceremonies, Christmas parties, performant employees are also awarded in the firm of first interviewed manager; in the second firm - there are values, norms and regulations, stories on the company successes. The organizational culture is based, for both organizations, and according to the managers, on achieving goals (and implicitly consumer satisfaction), but also on fulfilling employee needs, teamwork and friendship. 


\section{Conclusions and discussions}

With regard to the presence of team spirit and support, cooperation among co-workers, as well as the existence of a positive atmosphere, depicting that of a united team, according to the answers provided by the interviewees, help and cooperation are available within the team, especially in the IT and banking sectors (all of the respondents), for three quarters of the RD sectors, two thirds of the advertising sector and for only a half of the employees of the higher education sector. As far as the understanding and help received from the hierarchic superior are concerned, three quarters of the interviewees of the banking and higher education sectors are content with their managers' attitude - the superior "listens to them", although this does not change much of the situation; they are followed by the employees of the IT sector (two thirds), adverting and RD (half of the interviewed employees of these sectors).

From the point of view of the organizational culture, all the interviewed employees of the advertising, IT and banking sector experienced the presence within the company of some forms of organizational culture (Christmas parties, co-workers' anniversaries, teambuildings, symbolic awarding of employees with significant results in the advertising and IT sectors, and also written and unwritten internal norms and values in the banking sector; adding to that, there are myths on the founders in the multinational companies of these sectors). Only half of the interviewees without leadership attributions from the higher education sector admit to the presence of an organizational culture in their institution (represented through parties at the end of the semester and co-worker anniversaries); in the public funded RD sector, employees reportedly did not experience manifestations of any type of "visible artifacts" or values of organizational culture (according to Schein's three levels of manifestations of organizational culture).

According to the answers of the majority of the interviewees without any leadership role, in the advertising-marketing sector the climate is based on human relations and friendship (in the small Romanian agencies) and on co-worker competition and task achievement (in the multinational agencies); in the IT sector, climate is based on human relations, friendship, as well as on accomplishing goals, discipline and respect for rules; in the banking sector - on discipline and obeying rules followed by competition among co-workers and task achievement; in the RD private institutes on achieving goals, while in the public RD institutes on freedom, creativity as well as competition between colleagues; in the higher education sector on accomplishing goals, accompanied by encouraging initiative and creativity, along with competition. With respect to the theoretical approaches set as a ground for the methodological frame, the research confirmed the cultural approach and the collective basis for forming the organizational climate (climate is rather the result of an emerging collective interpretations, instead of a sum of separate individual perceptions). The picture of climate dimensions has been very different from one sector to other: from autonomy, teamwork, creativity and friendship, on one extreme, to discipline, respect for rules and accomplishing goals, on the other extreme.

On the other hand, while the results confirmed the validity of the cultural approach, the concept of Nonaka et al. (the "ba" climate) was not identified in the Romanian knowledgeintensive organizations. Although several values that improve performance have been identified (such as accomplishing goals, teamwork, obeying rules) the concept of "ba" climate referred to a set of variables that combined in order to enable the knowledge management process. In the cases of the organizations in the sample, the set of variables was different from 
one sector to another, showing that in the Romanian intensive-knowledge organizations there is not yet a unitary basis for stimulating performance and conversion of knowledge.

In all these five economic knowledge-intensive business services sectors, the perception of interviewed managers is in agreement with that of the sector's responding employees without any leadership role.

In knowledge-intensive organizations, the rigid, hierarchical and control-based management is recommended to be replaced with a management of organizational culture, of shared meanings, of a common identity, meant to motivate and to loyalize self-responsible expert-employees. The results of our research points out, according both to interviewed employees and managers, a large presence in their organizations of the main features that Alvesson associates with the term "organizational culture in knowledge-intensive organizations": team spirit and cooperation among colleagues (which facilitate sharing of meanings and building a common identity, in order to counter ambiguity specific to nature of their work); positive atmosphere due also to working with collaborators-managers or teammate-managers, not hierarchical superiors (collaborative relationships from an equal footing with superiors strengthen self-esteem and thus motivate "golden collars" workers); awareness of artifacts and values, as constitutive elements of organizational culture from the first two levels in Schein's vision (with the role of creating and building a common identity to employees, that compensates uncertainty caused by subjective evaluation of their work quality). Differences are due to organization size (small / large) and source of capital (multinational / Romanian, budget / private).

Far from covering the entire topic of organizational culture and climate in knowledge-intensive organizations, specific to transition to the knowledge economy, the paper presents the results of a qualitative research, using the interview guide, on the employees and managers of the five knowledge-intensive services sectors in Romanian economy, about their perceptions of organizational culture and climate in the organization where they work. The results of this descriptive and exploratory research will be the starting point for a new extensive, quantitative research about culture and organizational climate, using a questionnaire survey, applied on representative samples of employees and managers in the knowledge-intensive business services (KIBS) sector in our country, so that the new research results should be generalized for the whole Romanian KIBS sector.

\section{Note}

${ }^{1}$ The field research in this paper represents a part from the more extensive research conducted within the project "Economic scientific research, support for welfare and human development in European context", supported by the Sectorial Operational Programme Human Resources Development 2007-2013 (SOP HRD), financed from the European Social Fund and by the Romanian Government under the contract number SOP HRD/89/1.5/S/62988.

\section{References}

Alvesson, M. (2001). Knowledge work: ambiguity, image and identity. Human Relations, 54 (7), 863-886. Alvesson, M. (2002). Understanding Organizational Culture. London: Sage Publications.

Alvesson, M. (2004). Knowledge Work and Knowledge-Intensive Firms. Oxford: Oxford University Press. 
Balmer, J.M.T. \& Gray, E.R. (2000). Corporate identity and corporate communications: Creating a competitive advantage. Corporate Communications: An International Journal, Vol. 4 No. 4, 1999, 171-176

Bromley, D.B. (1993), Reputation, Image and Impression Management. London: Wiley.

Bromley, D.B. (2001). Relationships between personal and corporate reputation. European Journal of Marketing, 35 (3/4), 316-334.

Denison, D. (1996). What is the difference between organizational culture and organizational climate? A native's point of view on a decade of paradigm wars. Academy of Management Review, 21 (3), 619-654.

Donaldson, L. (2001). Reflections on Knowledge and Knowledge-Intensive Firms. Human Relations, vol. 54, iss. 7, 955-963.

Dowling, G. R. (2001). Creating corporate reputations: Identity, image and performance. Oxford: Oxford University Press.

Dowling, G. (2004). Corporate Reputations: Should you Compete on Yours?. California Management Review, 46, 19-36.

Hatch, M. J. \& Schultz, M. (1997). Relations between organizational culture, identity and image. European Journal of Marketing, 31 (5/6), 1997, 356-365.

Hellriegel, D. \& Slocum, J. W. (1974). Organizational climate: measures, research and contingencies. Academy of Management Journal, 17 (2), 255-280.

Leovaridis, C. (2008). Inovația în organizațiile intensiv-cognitive din sectorul serviciilor [Innovation in knowledge-intensive organizations in the services sector], in E. Avram (ed.), Psihologia in organizațiile modern [Psychology in modern organizations]. București: Editura Universitară, 257-270.

Leovaridis, C. (2013). Noi caracteristici ale calității vieții în contextul economiei cunoașterii și al competitiei pe plan european. Aspecte organizaționale și manageriale [New characteristics of life quality in the context of knowledge economy and European competition. Organizational and managerial aspects]. București: Editura Expert.

Moran, E. T. \& Volkwein, J. W. (1992). The cultural approach to the formation of organizational climate. Human Relations, 45 (1), 18-47.

Nonaka, I., von Krogh G. \& Voelpel, S. (2006). Organizational Knowledge Creation Theory: Evolutionary Paths and Future Advances. Organization Studies, 27, 1179-1210.

Ravasi, D. \& Schultz, M. (2006). Responding to organizational identity threats:

Exploring the role of organizational culture. Academy of Management Journal, 49 (3), 433-458.

Schein, Edgar H. (1984). Coming to a New Awareness of Organizational Culture. Sloan Management Review, 25:2, 3-17.

Schein, E.H. (1990). Organizational Culture. American Psychologist, 45(2), 109-119.

Swart, J., Kinnie, N. (2003). Sharing knowledge in knowledge-intensive firms. Human Resource Management Journal, Vol. 13, Iss. 2, 60-75.

Thite, M. (2004). Strategic Positioning of HRM in Knowledge-based Organizations. The Learning Organization, vol. 11, Iss. 1, 28-44.

Whetten, D. A. \& Mackey, A. (2002). A social actor conception of organizational identity and its implications for the study of organizational reputation. Business \& Society 41 (4), 393-414. 
Annex 1. The demographic characteristics of the people interviewed

\begin{tabular}{|c|c|c|c|c|}
\hline Respondent & Age & Gender & Position & $\begin{array}{l}\text { Employee }(E) \text { or } \\
\text { manager }(M)\end{array}$ \\
\hline \multicolumn{5}{|l|}{ IT\&C sector } \\
\hline IT.E.1 & 24 & M & junior programmer & $E$ \\
\hline IT.E.2 & 32 & $M$ & software engineer & $E$ \\
\hline IT.E.3 & 34 & M & programmer & $E$ \\
\hline IT.E.4 & 23 & $M$ & programmer & $E$ \\
\hline IT.E.5 & 31 & $M$ & system engineer & $E$ \\
\hline IT.E.6 & 25 & $M$ & programmer & $E$ \\
\hline IT.E.7 & 28 & $M$ & programmer & $E$ \\
\hline IT.E.8 & 30 & M & programmer & $E$ \\
\hline IT.E.9 & 24 & $M$ & programmer & $E$ \\
\hline IT.E.10 & 35 & M & programmer & $E$ \\
\hline IT.E.11 & 26 & $M$ & programmer & $E$ \\
\hline IT.E.12 & 23 & $\mathrm{~F}$ & programmer & $E$ \\
\hline IT.E.13 & 34 & $M$ & software engineer & $E$ \\
\hline IT.E.14 & 38 & M & network engineer & $E$ \\
\hline IT.E.15 & 25 & $\mathrm{~F}$ & software engineer & $E$ \\
\hline IT.M.1 & 41 & M & project manager development department & M \\
\hline IT.M.2 & 46 & M & business manager South East Europe & M \\
\hline IT.M.3 & 39 & M & general manager & M \\
\hline \multicolumn{5}{|c|}{ Research \& development sector } \\
\hline R.E.1 & 23 & $\mathrm{~F}$ & junior client service & $E$ \\
\hline R.E.2 & 47 & $\mathrm{~F}$ & IIIrd degree scientific researcher, $\mathrm{PhD}$ & $E$ \\
\hline R.E.3 & 43 & $\mathrm{~F}$ & research assistant & $E$ \\
\hline R.E.4 & 32 & $\mathrm{~F}$ & IIIrd degree scientific researcher, PhD & $E$ \\
\hline R.E.5 & 34 & M & research assistant, $\mathrm{PhD}$ & $E$ \\
\hline R.E.6 & 36 & $\mathrm{~F}$ & Illrd degree scientific researcher & $\mathrm{E}$ \\
\hline R.E.7 & 39 & $\mathrm{~F}$ & IIIrd degree scientific researcher, $\mathrm{PhD}$ & $E$ \\
\hline R.E.8 & 33 & M & IIIrd degree scientific researcher, $\mathrm{PhD}$ & $E$ \\
\hline R.E.9 & 75 & M & Ist degree scientific researcher, $\mathrm{PhD}$ & $\mathrm{E}$ \\
\hline R.E.10 & 34 & M & IIIrd degree scientific researcher, $\mathrm{PhD}$ & $E$ \\
\hline R.E.11 & 20 & $\mathrm{~F}$ & research assistant & $E$ \\
\hline R.E.12 & 33 & $\mathrm{~F}$ & IIIrd degree scientific researcher, $\mathrm{PhD}$ & $E$ \\
\hline R.E.13 & 46 & $\mathrm{~F}$ & Ilnd degree scientific researcher, PhD & $E$ \\
\hline R.M.1 & 65 & M & scientific director, $\mathrm{PhD}$ & M \\
\hline R.M.2 & 62 & M & scientific director, $\mathrm{PhD}$ & M \\
\hline
\end{tabular}




\begin{tabular}{|c|c|c|c|c|}
\hline \multicolumn{5}{|c|}{ High education sector } \\
\hline E.E.1 & 38 & $\mathrm{~F}$ & lecturer, PhD & $E$ \\
\hline E.E.2 & 30 & $\mathrm{~F}$ & assistant & $E$ \\
\hline E.E.3 & 30 & M & assistant, $\mathrm{PhD}$ & $E$ \\
\hline E.E.4 & 29 & $\mathrm{~F}$ & assistant & $E$ \\
\hline E.E.5 & 33 & M & lecturer, PhD & $E$ \\
\hline E.E.6 & 32 & $\mathrm{~F}$ & assistant, $\mathrm{PhD}$ & $E$ \\
\hline E.E.7 & 53 & M & associate professor, $\mathrm{PhD}$ & $E$ \\
\hline E.E.8 & 25 & $\mathrm{~F}$ & assistant & $E$ \\
\hline E.E.9 & 34 & $\mathrm{~F}$ & lecturer, PhD & $E$ \\
\hline E.E.10 & 49 & M & associate professor, $\mathrm{PhD}$ & $E$ \\
\hline E.E.11 & 39 & $\mathrm{~F}$ & lecturer, PhD & $E$ \\
\hline E.E.12 & 35 & $\mathrm{~F}$ & lecturer, PhD & $E$ \\
\hline M.E.1 & 43 & $\mathrm{~F}$ & head of department & M \\
\hline M.E.2 & 50 & M & head of department & M \\
\hline \multicolumn{5}{|c|}{ Advertising-market sector } \\
\hline A.E.1 & 23 & M & copywriter & $E$ \\
\hline A.E.2 & 25 & M & copywriter & $E$ \\
\hline A.E.3 & 23 & $\mathrm{~F}$ & senior accout executive client service & $E$ \\
\hline A.E.4 & 24 & $\mathrm{~F}$ & copywriter & $E$ \\
\hline A.E.5 & 30 & $\mathrm{~F}$ & assistant manager & $\mathrm{E}$ \\
\hline A.E.6 & 24 & $\mathrm{~F}$ & accout executive client service & $E$ \\
\hline A.E.7 & 29 & M & junior PR executive & $\mathrm{E}$ \\
\hline A.E.8 & 23 & $\mathrm{~F}$ & online marketing specialist & $E$ \\
\hline A.E.9 & 25 & $\mathrm{~F}$ & accout executive client service & $E$ \\
\hline A.E.10 & 33 & $\mathrm{~F}$ & art director & $\mathrm{E}$ \\
\hline A.E.11 & 27 & $\mathrm{~F}$ & social media specialist & $E$ \\
\hline A.E.12 & 23 & $\mathrm{~F}$ & web copywriter & $E$ \\
\hline A.E.13 & 31 & $\mathrm{~F}$ & BTL Executive & $\mathrm{E}$ \\
\hline A.E.14 & 22 & M & junior copywriter & $E$ \\
\hline A.E.15 & 35 & $\mathrm{~F}$ & senior copywriter & $E$ \\
\hline A.M.1 & 37 & $\mathrm{~F}$ & business unit director & M \\
\hline A.M.2 & 35 & $\mathrm{~F}$ & manager of research department & M \\
\hline A.M.3 & 40 & $\mathrm{~F}$ & general manager & M \\
\hline
\end{tabular}




\begin{tabular}{|c|c|c|c|c|}
\hline \multicolumn{5}{|c|}{ Financial-banking sector } \\
\hline B.E.1 & 26 & M & client counselor & $E$ \\
\hline B.E.2 & 36 & $F$ & human resources coordinator & $E$ \\
\hline B.E.3 & 24 & $F$ & IT system administrator & E \\
\hline B.E.4 & 28 & $F$ & front office account administrator & E \\
\hline B.E.5 & 29 & $F$ & banking products coordinator & E \\
\hline B.E.6 & 27 & $M$ & banking products coordinator & E \\
\hline B.E.7 & 23 & $\mathrm{~F}$ & PR specialist & $E$ \\
\hline B.E.8 & 44 & $\mathrm{~F}$ & client counselor & E \\
\hline B.E.9 & 25 & $\mathrm{~F}$ & Telesales operator & E \\
\hline B.E.10 & 35 & $\mathrm{~F}$ & expert assistant & E \\
\hline B.E.11 & 26 & $M$ & sales analist & E \\
\hline B.E.12 & 34 & $F$ & quality coordinator & E \\
\hline B.M.1 & 38 & $F$ & manager of corporate credits department & M \\
\hline B.M.2 & 42 & $\mathrm{~F}$ & manager of leasing department & M \\
\hline
\end{tabular}




\section{Annex 2. Exemples of quotes from the respondents' answers at the interview-guide}

\section{IT\&C sector}

\begin{tabular}{|c|c|c|}
\hline Question & Respon-dent & Answer \\
\hline \multirow{5}{*}{$\begin{array}{l}\text { How does the } \\
\text { organizational culture of } \\
\text { your company manifest } \\
\text { (are there certain values, } \\
\text { norms, written or non- } \\
\text { written regulations, } \\
\text { specific symbols, } \\
\text { myths/stories on the } \\
\text { history/founders of the } \\
\text { company, are there } \\
\text { anniversaries organized } \\
\text { to celebrate the company, } \\
\text { employees, Christmas, } \\
\text { the awarding of } \\
\text { employees etc? }\end{array}$} & IT.E.5 & $\begin{array}{l}\text { There are Christmas parties and anniversaries, but inside smaller teams from } \\
\text { various departments. }\end{array}$ \\
\hline & IT.E.8 & $\begin{array}{l}\text { There are values, norms, written regulations, organization stories, anniversary } \\
\text { and awards' ceremonies. }\end{array}$ \\
\hline & IT.E.15 & $\begin{array}{l}\text { There are written and unwritten norms on interaction, individual behavior, } \\
\text { relations between employees are consolidated both during work as well as } \\
\text { through teambuilding, Christmas parties etc. Awards are given based on the } \\
\text { twice-a-year evaluations, or based on the company's good results. }\end{array}$ \\
\hline & IT.M.1 & $\begin{array}{l}\text { Christmas parties, along with organizing company anniversaries and awarding } \\
\text { employees. }\end{array}$ \\
\hline & IT.M.2 & $\begin{array}{l}\text { There are no common events in the company, but rather department events. } \\
\text { At SEE Software it is common to spend together two weeks per year abroad, } \\
\text { one in spring and one in autumn, to relax and discuss business goals. }\end{array}$ \\
\hline \multirow{6}{*}{$\begin{array}{l}\text { Do your co-workers help } \\
\text { and support you? What } \\
\text { about your hierarchical } \\
\text { superior? Is there } \\
\text { cooperation, help and a } \\
\text { positive atmosphere } \\
\text { among colleagues, do you } \\
\text { feel part of a groups or do } \\
\text { you work in isolation from } \\
\text { the other co-workers?", } \\
\text { "Your ierachical supervisor } \\
\text { is open / available to listen } \\
\text { to your work-related } \\
\text { issues?" }\end{array}$} & IT. E.3 & $\begin{array}{l}\text { I get along well with my co-workers, we help each other; we also have good } \\
\text { relations with the direct manager. Generally, there is a sense of a team spirit } \\
\text { present. }\end{array}$ \\
\hline & IT.E.7 & The pleasant atmosphere is what I appreciate most at this job. \\
\hline & IT.E.8 & $\begin{array}{l}\text { Given that the team is composed of one local part and another part abroad, } \\
\text { there are two types of communication - a very good one with the local co- } \\
\text { workers/managers and a faulty one with those from abroad. }\end{array}$ \\
\hline & IT.E.1 & $\begin{array}{l}\text { There is a certain competition among colleagues - all those who enter have a } \\
\text { limited contract and they need to stand out so that they can get an unlimited one. }\end{array}$ \\
\hline & IT.E.2 & $\begin{array}{l}\text { Cooperation and help are available, but because of deadlines there is not } \\
\text { much time left for a positive atmosphere. }\end{array}$ \\
\hline & IT.E.14 & My superior did not listen or help me, he always imposed his point of view. \\
\hline \multirow{7}{*}{$\begin{array}{l}\text { How would you } \\
\text { characterize the climate } \\
\text { within the company (by } \\
\text { highlighting competition, } \\
\text { promotion of exceptional } \\
\text { individuals or human } \\
\text { relations, friendship, } \\
\text { teamwork; the } \\
\text { achievement of company } \\
\text { objectives or employee } \\
\text { satisfaction; } \\
\text { subordination and } \\
\text { respect for regulations or } \\
\text { autonomy and employee } \\
\text { freedom; compliance and } \\
\text { discipline or initiative, } \\
\text { creativity; risk/defensive } \\
\text { attitude etc.)? }\end{array}$} & IT.E.3 & $\begin{array}{l}\text { The focus is on teamwork, but the main goal is to accomplish objectives in } \\
\text { time; however, they are also interested in employee satisfaction - for } \\
\text { instance, we receive once a month a Health Survey, which is annonymous } \\
\text { and requests information on the team's level of content: whether we like our } \\
\text { jobs, whether we would like to change anything etc. Risk management is very } \\
\text { important for the company: they want to know earlier whether a task is likely } \\
\text { to miss the deadline, the reasons for happening and whether the reasons are } \\
\text { strong ones, the management initiates discussions on possible solutions, } \\
\text { which could mean a postponing or even cancellation of the respective task. } \\
\text { The main goal is to have the final product in due time, with the least amount } \\
\text { of risks; it is even preferable to give up on some improvements, should they } \\
\text { engender higher risks. }\end{array}$ \\
\hline & IT.E.12 & $\begin{array}{l}\text { Company climate is characterized by teamwork, cooperation, reciprocal help, } \\
\text { obeying rules and employee motivation. }\end{array}$ \\
\hline & IT.E.8 & The emphasis is on subordination and obeying rules; compliance also. \\
\hline & IT.E.14 & $\begin{array}{l}\text { The climate is based on subordination, respecting work procedures and } \\
\text { deadlines. }\end{array}$ \\
\hline & IT.M.1 & $\begin{array}{l}\text { Company climate is characterized by: teamwork, achieving company } \\
\text { objectives, subordination and respecting rules. }\end{array}$ \\
\hline & IT.M.2 & $\begin{array}{l}\text { The organizational climate is a formal one, in which rules and goal } \\
\text { achievement come first. }\end{array}$ \\
\hline & IT.M.3 & $\begin{array}{l}\text { Company climate is based on teamwork, discipline and promotes creativity } \\
\text { through salary bonuses. }\end{array}$ \\
\hline
\end{tabular}




\section{Research-development sector}

\begin{tabular}{|c|c|c|}
\hline Question & Respon-dent & Answer \\
\hline \multirow{5}{*}{$\begin{array}{l}\text { How does the organizational } \\
\text { culture of your company } \\
\text { manifest (are there certain } \\
\text { values, norms, written or } \\
\text { non-written regulations, } \\
\text { specific symbols, } \\
\text { myths/stories on the } \\
\text { history/founders of the } \\
\text { company, are there } \\
\text { anniversaries organized to } \\
\text { celebrate the company, } \\
\text { employees, Christmas, the } \\
\text { awarding of employees etc? }\end{array}$} & R.E.2 & There are no such elements of an organizational culture. \\
\hline & R.E.10 & We don't have an organizational culture. \\
\hline & R.E.13 & $\begin{array}{l}\text { There are work regulations and job descriptions, we celebrate employee } \\
\text { birthdays...There are no awards. It is a poorly structured organizational } \\
\text { culture. }\end{array}$ \\
\hline & R.M.2 & $\begin{array}{l}\text { There are no forms of organizational culture, employee birthdays are } \\
\text { celebrated even more rarely than we used to before 1989; even though the } \\
\text { society has opened, people have closed themselves to it. }\end{array}$ \\
\hline & R.M.1 & $\begin{array}{l}\text { Firstly, there is professional ethics. Then there are the institute's organization } \\
\text { and functioning regulations (IOR, The Ethics Code), which manage the } \\
\text { institute's activity, relations between employees, between superiors and } \\
\text { subordinates, between the institute and the mother company, the Romanian } \\
\text { Academy. The Internal Managerial Control System regulates on the relations } \\
\text { within the institute, while the } 28 \text { procedures of the system establish precise } \\
\text { tasks and assignments such as document circulation. This entire system is } \\
\text { legally regulated and individualizes, by attributions and relations, each } \\
\text { department of the institute. }\end{array}$ \\
\hline \multirow{5}{*}{$\begin{array}{l}\text { Do your co-workers help } \\
\text { and support you? What } \\
\text { about your hierarchical } \\
\text { superior? Is there } \\
\text { cooperation, help and a } \\
\text { positive atmosphere among } \\
\text { colleagues, do you feel part } \\
\text { of a groups or do you work } \\
\text { in isolation from the other } \\
\text { co-workers?", "Your } \\
\text { ierachical supervisor is open } \\
\text { / available to listen to your } \\
\text { work-related issues?" }\end{array}$} & R.E.6 & $\begin{array}{l}\text { Within my working team, there are cooperation, support, help and a positive } \\
\text { atmosphere among the co-workers; I feel that I am a part of this group. My } \\
\text { superior is willing to listen to issues related to the workplace. }\end{array}$ \\
\hline & R.E.5 & $\begin{array}{l}\text { Usually, I am supported by the colleagues and the manager. Unfortunatley, } \\
\text { there is enough envy among the co-workers, so I mostly work alone or in a } \\
\text { very small team. }\end{array}$ \\
\hline & R.E.10 & $\begin{array}{l}\text { Being mostly an individual type of work, there is a small degree of } \\
\text { cooperation. }\end{array}$ \\
\hline & R.E.8 & $\begin{array}{l}\text { My co-workers didn't offer me any support, but my superior did and he would } \\
\text { offer me support also in coordinating academic activities. }\end{array}$ \\
\hline & R.E.1 & My superior only appears to be willing to listen to work-related issues. \\
\hline \multirow{4}{*}{$\begin{array}{l}\text { How would you characterize } \\
\text { the climate within the } \\
\text { company (by highlighting } \\
\text { competition, promotion of } \\
\text { exceptional individuals or } \\
\text { human relations, friendship, } \\
\text { teamwork; the achievement } \\
\text { of company objectives or } \\
\text { employee satisfaction; } \\
\text { subordination and respect } \\
\text { for regulations or autonomy } \\
\text { and employee freedom; } \\
\text { compliance and discipline or } \\
\text { initiative, creativity; } \\
\text { risk/defensive attitude etc.)? }\end{array}$} & R.E.4 & $\begin{array}{l}\text { Friendship, teamwork and competition co-exist; one aims at achieving the } \\
\text { institution's goals; there is also an emphasis on employee freedom, initiative } \\
\text { and creativity. }\end{array}$ \\
\hline & R.E.7 & $\begin{array}{l}\text { Employee competition is sometimes pretty strong, comprising even envy. } \\
\text { There is also a strong promotion of exceptional individual accomplishments. } \\
\text { Usually, we work as a team, respecting quite strictly the hierarchy. However, } \\
\text { there is frequent encouragement of freedom of expression and employee } \\
\text { creativity. }\end{array}$ \\
\hline & R.M.1 & $\begin{array}{l}\text { The climate is characterized both by achieving goals, as long as every } \\
\text { researcher has a yearly working plan, but also by the freedom of action, } \\
\text { initiative and creativity which are fundamental in the research activity. }\end{array}$ \\
\hline & R.M.2 & $\begin{array}{l}\text { There is roughness among people, but the small conflicts that have emerged } \\
\text { have been solved by tete-a-tete discussions, so that tension diminished and } \\
\text { did not affect the local climate of the organization. The rest, meaning human } \\
\text { relations, are to be tackled by the people themselves, as the management } \\
\text { cannot intervene there. }\end{array}$ \\
\hline
\end{tabular}




\section{Higher education sector}

\begin{tabular}{|c|c|c|}
\hline Question & Respon-dent & Answer \\
\hline \multirow{5}{*}{$\begin{array}{l}\text { How does the organizational } \\
\text { culture of your company } \\
\text { manifest (are there certain } \\
\text { values, norms, written or } \\
\text { non-written regulations, } \\
\text { specific symbols, } \\
\text { myths/stories on the } \\
\text { history/founders of the } \\
\text { company, are there } \\
\text { anniversaries organized to } \\
\text { celebrate the company, } \\
\text { employees, Christmas, the } \\
\text { awarding of employees etc? }\end{array}$} & E.E.1 & $\begin{array}{l}\text { There are some anniversaries organized, but not regularly. There are } \\
\text { Christmas parties, sometimes even end of term parties. }\end{array}$ \\
\hline & E.E.2 & $\begin{array}{l}\text { There are sometimes small ceremonies organized in order to celebrate } \\
\text { our colleagues, for Christmas or on special occasions. }\end{array}$ \\
\hline & E.E.3 & $\begin{array}{l}\text { Whenever there are important commemorations regarding the university, } \\
\text { one remembers the legends surrounding the founding of the university. }\end{array}$ \\
\hline & E.E.11 & $\begin{array}{l}\text { The university has its own organizational culture, promoting itself } \\
\text { through various ceremonies (e.g. celebrating } X \text { years from its founding), } \\
\text { performing different cultural activities on a university level, evoking the } \\
\text { personality who gave the name to the university etc. }\end{array}$ \\
\hline & E.M.1 & $\begin{array}{l}\text { There is an organizational culture characterized by unity as a main } \\
\text { value, and confidence in the elected representatives to the detriment of } \\
\text { external factors. There are also the founding hero of the university and } \\
\text { myths about the faculty's first years. }\end{array}$ \\
\hline \multirow{6}{*}{$\begin{array}{l}\text { Do your co-workers help and } \\
\text { support you? What about } \\
\text { your hierarchical superior? Is } \\
\text { there cooperation, help and } \\
\text { a positive atmosphere } \\
\text { among colleagues, do you } \\
\text { feel part of a groups or do } \\
\text { you work in isolation from } \\
\text { the other co-workers?", } \\
\text { "Your ierachical supervisor is } \\
\text { open / available to listen to } \\
\text { your work-related issues?" }\end{array}$} & E.E.9 & $\begin{array}{l}\text { My co-workers supported me in my activity. There is cooperation among } \\
\text { the members of the department. }\end{array}$ \\
\hline & E.E.2 & Not all colleagues are willing to help or cooperate. \\
\hline & E.E.5 & $\begin{array}{l}\text { My colleagues didn't support me, but the hierarchic superior did, by } \\
\text { offering his support on the level of teaching coordination. }\end{array}$ \\
\hline & E.E.12 & $\begin{array}{l}\text { There are some colleagues I get along well with. The management also } \\
\text { became more transparent lately. Generally, the working team is ok, nice, } \\
\text { interesting, helpful. }\end{array}$ \\
\hline & E.E.4 & $\begin{array}{l}\text { I discuss with my superiors about various problems that occur while } \\
\text { doing my job, but I don't always succeed in chaging the situation. }\end{array}$ \\
\hline & E.E.11 & The relation with the hierarchic superiors is a good one. \\
\hline \multirow{6}{*}{$\begin{array}{l}\text { How would you characterize } \\
\text { the climate within the } \\
\text { company (by highlighting } \\
\text { competition, promotion of } \\
\text { exceptional individuals or } \\
\text { human relations, friendship, } \\
\text { teamwork; the achievement } \\
\text { of company objectives or } \\
\text { employee satisfaction; } \\
\text { subordination and respect for } \\
\text { regulations or autonomy and } \\
\text { employee freedom; } \\
\text { compliance and discipline or } \\
\text { initiative, creativity; } \\
\text { risk/defensive attitude etc.)? }\end{array}$} & E.E.12 & $\begin{array}{l}\text { Competition, individual promotion, accomplishing faculty objectives, } \\
\text { initiative, team creation. }\end{array}$ \\
\hline & E.E.4 & $\begin{array}{l}\text { Accomplishing the institution's goals is very important, sometimes by } \\
\text { making sacrifices regarding employees' satisfaction. The latter also } \\
\text { enjoy a high degree of autonomy, are encouraged to have initiative and } \\
\text { show creativity. }\end{array}$ \\
\hline & E.E.6 & $\begin{array}{l}\text { Friendship based on affinity, similar profiles and preoccupations and, as } \\
\text { far as the faculty is concerned, I feel that they expect conformity in the } \\
\text { chosen direction and also with regard to professional preoccupations. } \\
\text { The climate is positive regarding relations between people, but rather } \\
\text { rigid as far as hierarchic relations are concerned. }\end{array}$ \\
\hline & E.E.5 & $\begin{array}{l}\text { The climate in the organizations is based on teamwork within the } \\
\text { research projects, achieving the institution's goals, sometimes by making } \\
\text { sacrifices regarding employees' satisfaction. }\end{array}$ \\
\hline & E.M.1 & $\begin{array}{l}\text { The climate is pretty rough, emphasizing competition, career, achieving } \\
\text { goals, competence, modernity (adaptability to market tendencies and } \\
\text { "customer" demands). There are also conjugated values such as humor, } \\
\text { teamwork, autonomy and flexibility with regard to work presense, which } \\
\text { produce a certain agreable side of the climate. }\end{array}$ \\
\hline & E.M.2 & The climate is based on the interest in the educational act. \\
\hline
\end{tabular}


Advertising-marketing sector

\begin{tabular}{|c|c|c|}
\hline Question & Respondent & Answer \\
\hline \multirow{11}{*}{$\begin{array}{l}\text { How does the } \\
\text { organizational } \\
\text { culture of your } \\
\text { company manifest } \\
\text { (are there certain } \\
\text { values, norms, } \\
\text { written or non- } \\
\text { written regulations, } \\
\text { specific symbols, } \\
\text { myths/stories on } \\
\text { the } \\
\text { history/founders of } \\
\text { the company, are } \\
\text { there } \\
\text { anniversaries } \\
\text { organized to } \\
\text { celebrate the } \\
\text { company, } \\
\text { employees, } \\
\text { Christmas, the } \\
\text { awarding of } \\
\text { employees etc? }\end{array}$} & A.E.3 & $\begin{array}{l}\text { The office was decorated with stickers bearing funny messages, paintings, it has lots } \\
\text { of opening doors and the furniture combines raw green and white wood and coloured } \\
\text { glass. }\end{array}$ \\
\hline & A.E.6 & As a symbol, there is a red dot, bearing words such as: Creative, budget, Smile. \\
\hline & A.E.7 & $\begin{array}{l}\text { The employees with best results in their work would receive a symbolic award, } \\
\text { consisting of a diploma of Employee of the month, or a marketing/branding book. }\end{array}$ \\
\hline & A.E.8 & $\begin{array}{l}\text { I believe that values refer to quality, teamwork and the let's have more initiative and } \\
\text { be more entrepreneurial attitude. The norms refer to the procedure of filling in the } \\
\text { timesheet, card clocking, booking the conference room } 2 \text { days in advance; there are } \\
\text { also unwritten rules, which you learn in time. }\end{array}$ \\
\hline & A.E.11 & $\begin{array}{l}\text { We have our inside jokes, which geeks from outside our field of work cannot } \\
\text { understand. }\end{array}$ \\
\hline & A.E.13 & $\begin{array}{l}\text { As a ritual I would name the coffee making in the morning, when employees } \\
\text { frequently meet in the company kitchen }\end{array}$ \\
\hline & A.E.12 & $\begin{array}{l}\text { We participated in karting together and there are also some attempts of organizing } \\
\text { internal board games championships. }\end{array}$ \\
\hline & A.E.4 & $\begin{array}{l}\text { We had these myths on the company veterans; they repeated on and on the values } \\
\text { of the company according to its founder. We found books written by them on the } \\
\text { desk. We have also received backpacks, badges, laces, T-shirts inscribed with these } \\
\text { values and we even went on a teambuilding based on the company's } 7 \text { values. }\end{array}$ \\
\hline & A.M.1 & $\begin{array}{l}\text { Organizational culture is strongly connected with the company founder. His quotes } \\
\text { or the visuals he developed can be found everywhere around in the agency. Even } \\
\text { the fact that we have an outdoor relaxing place, a garden, is part of the management } \\
\text { principles he developed. On a local level, culture comprises the following events: } 10 \\
\text { free days in January, } 2 \text { teambuildings/year, Agency Day, Earth Day (the day in } \\
\text { which we change something in the agency in order to be more responsible towards } \\
\text { the environment), } 1^{\text {st }} \text { of June - Employees' Children Day, Secret Santa, Christmas } \\
\text { Party (there is a party for the employees' children and one for the employees), } \\
\text { parties to celebrate employee success (awards). }\end{array}$ \\
\hline & A.M.2 & $\begin{array}{l}\text { There are definitely written and unwritten regulations, as well as stories regarding } \\
\text { the agency founders. When the mother company celebrated ten years of existence, } \\
\text { there was a meeting of all branches employees, but this is not done on a yearly } \\
\text { basis!. }\end{array}$ \\
\hline & A.M.3 & $\begin{array}{l}\text { We are an united team, which is at the beginning of its path and organizational } \\
\text { culture is continuously being developed. }\end{array}$ \\
\hline \multirow{6}{*}{$\begin{array}{l}\text { Do your co- } \\
\text { workers help and } \\
\text { support you? What } \\
\text { about your } \\
\text { hierarchical } \\
\text { superior? Is there } \\
\text { cooperation, help } \\
\text { and a positive } \\
\text { atmosphere } \\
\text { among colleagues, } \\
\text { do you feel part of } \\
\text { a groups or do you } \\
\text { work in isolation } \\
\text { from the other co- } \\
\text { workers?", "Your } \\
\text { ierachical } \\
\text { supervisor is open } \\
\text { / available to listen } \\
\text { to your work- } \\
\text { related issues?" }\end{array}$} & A.E.9 & $\begin{array}{l}\text { The agency was my second family. We always helped each other, and offered } \\
\text { support and advice when needed. We almost knew everything about each other. }\end{array}$ \\
\hline & A.E.10 & $\begin{array}{l}\text { We are young and we have a lot of energy and enthusiasm. We are all friends, from } \\
\text { the boss to the most recently employed guy, and we get along well both at the office } \\
\text { and outside the office. If one of us is overloaded with tasks and we could take some } \\
\text { of them, we would do it gladly. }\end{array}$ \\
\hline & A.E.8 & $\begin{array}{l}\text { There was competition between the co-workers, and no cooperation, as each of } \\
\text { them would work in isolation from the others. }\end{array}$ \\
\hline & A.E.15 & $\begin{array}{l}\text { I don't feel like being part of a group, the atmosphere is tense, workloads are high } \\
\text { and so is pressure. }\end{array}$ \\
\hline & A.E.5 & $\begin{array}{l}\text { My superiors always listen to me, offer the necessary support and take my opinions } \\
\text { into account for solving issues. }\end{array}$ \\
\hline & A.E.14 & $\begin{array}{l}\text { Only the managers seemed to be separated from the team, and the creative director } \\
\text { was especially tough and authoritative. }\end{array}$ \\
\hline
\end{tabular}




\begin{tabular}{|c|c|c|}
\hline $\begin{array}{l}\text { How would you } \\
\text { characterize the } \\
\text { climate within the } \\
\text { company (by } \\
\text { highlighting } \\
\text { competition, } \\
\text { promotion of }\end{array}$ & A.E.11 & $\begin{array}{l}\text { Most often one can enjoy cooperation and teamwork - we help each other when } \\
\text { necessary. At the same time, everyone is free to establish his own working pace, as } \\
\text { long as deadlines are met and the results are those expected. }\end{array}$ \\
\hline $\begin{array}{l}\text { individuals or } \\
\text { human relations, } \\
\text { friendship, } \\
\text { teamwork; the } \\
\text { achievement of } \\
\text { company }\end{array}$ & A.E.4 & $\begin{array}{l}\text { The creatives have a lot of ego in general; that's why it is normal and healthy to } \\
\text { ensure a competitive environment. One emphasizes more the achievement of } \\
\text { company goals - should that happen, employee happiness is a natural } \\
\text { consequence. }\end{array}$ \\
\hline $\begin{array}{l}\text { employee } \\
\text { satisfaction; } \\
\text { subordination and } \\
\text { respect for } \\
\text { regulations or } \\
\text { autonomy and }\end{array}$ & A.M.1 & $\begin{array}{l}\text { Given that it is a work that involves creativity and a final impact result we consider } \\
\text { ourselves lucky that employee satisfaction derives from the work they perform. } \\
\text { Although the climate may be tense when under the pressure of a tight deadline, it is } \\
\text { most often governed by friendship and teamwork. }\end{array}$ \\
\hline $\begin{array}{l}\text { freedom; } \\
\text { compliance and } \\
\text { discipline or } \\
\text { initiative, creativity; } \\
\text { risk/defensive } \\
\text { attitude etc.)? }\end{array}$ & A.M.3 & $\begin{array}{l}\text { The words that better describe the company climate are: friendship, informal } \\
\text { relations, emphasis on task-solving rather than on the hours spent at the office, } \\
\text { teamwork, autonomy, emphasis on team vs. personal satisfaction (personal } \\
\text { development). }\end{array}$ \\
\hline
\end{tabular}


Financial-banking sector

\begin{tabular}{|c|c|c|}
\hline Question & Respondent & Answer \\
\hline \multirow{5}{*}{$\begin{array}{l}\text { How does the organizational } \\
\text { culture of your company } \\
\text { manifest (are there certain } \\
\text { values, norms, written or non- } \\
\text { written regulations, specific } \\
\text { symbols, myths/stories on the } \\
\text { history/founders of the company, } \\
\text { are there anniversaries } \\
\text { organized to celebrate the } \\
\text { company, employees, } \\
\text { Christmas, the awarding of } \\
\text { employees etc? }\end{array}$} & B.E.1 & $\begin{array}{l}\text { The organizational culture is based on values, norms and written } \\
\text { regulations. }\end{array}$ \\
\hline & B.E.11 & $\begin{array}{l}\text { The company organizational culture manifests through organizing } \\
\text { company and employee anniversaries, Christmas parties, awarding } \\
\text { employees. }\end{array}$ \\
\hline & B.E.9 & $\begin{array}{l}\text { The symbol of this company is the Umbrella, which is considered a } \\
\text { form of protection for the customers requesting our help. The employer } \\
\text { organizes monthly award festivities for the best employees, but also } \\
\text { Christmas parties and for any other holidays throughout the year. }\end{array}$ \\
\hline & B.M.1 & $\begin{array}{l}\text { There are company and employee award ceremonies, Christmas } \\
\text { parties, performant employees are also awarded. }\end{array}$ \\
\hline & B.M.2 & $\begin{array}{l}\text { There are well-known values among the group, internal norms and } \\
\text { regulations, a day per year is dedicated to the group, a time when } \\
\text { employees and managers discuss together about values, successful } \\
\text { and less successful stories, the role each has within the organization } \\
\text { and how he/she could contribute to goal achievement. }\end{array}$ \\
\hline \multirow{4}{*}{$\begin{array}{l}\text { Do your co-workers help and } \\
\text { support you? What about your } \\
\text { hierarchical superior? Is there } \\
\text { cooperation, help and a positive } \\
\text { atmosphere among colleagues, } \\
\text { do you feel part of a groups or } \\
\text { do you work in isolation from the } \\
\text { other co-workers?", "Your } \\
\text { ierachical supervisor is open / } \\
\text { available to listen to your work- } \\
\text { related issues?" }\end{array}$} & B.E.3 & $\begin{array}{l}\text { I work in a positive atmosphere, cooperate with my co-workers, we } \\
\text { help each-other. I feel that I am part of a team. }\end{array}$ \\
\hline & B.E.8 & $\begin{array}{l}\text { Yes, I feel that I am receiving help, and feel like belonging to a team } \\
\text { and enjoying a positive atmosphere. }\end{array}$ \\
\hline & B.E.5 & $\begin{array}{l}\text { The manager hardly has time as he is always involved in large } \\
\text { projects and is constantly attenting meetings. }\end{array}$ \\
\hline & B.E.6 & $\begin{array}{l}\text { My boss listens to my issues; that doesn't mean that they are } \\
\text { automatically solved. }\end{array}$ \\
\hline \multirow{6}{*}{$\begin{array}{l}\text { How would you characterize the } \\
\text { climate within the company (by } \\
\text { highlighting competition, } \\
\text { promotion of exceptional } \\
\text { individuals or human relations, } \\
\text { friendship, teamwork;the } \\
\text { achievement of company } \\
\text { objectives or employee } \\
\text { satisfaction; subordination and } \\
\text { respect for regulations or } \\
\text { autonomy and employee } \\
\text { freedom; compliance and } \\
\text { discipline or initiative, creativity; } \\
\text { risk/defensive attitude etc.)? }\end{array}$} & B.E.7 & $\begin{array}{l}\text { Given the field of activity, which is banking, compliance is rather strong } \\
\text { - discipline is often encouraged to the detriment of creativity. }\end{array}$ \\
\hline & B.E.2 & $\begin{array}{l}\text { The climate is characterized by subordination, obeying rules and an } \\
\text { emphasis on achieving goals. }\end{array}$ \\
\hline & B.E.3 & Ther is an emphasis on competition and teamwork. \\
\hline & B.E.9 & $\begin{array}{l}\text { Every month we have competitions between teams, on a regular basis, } \\
\text { and we go out with the co-workers, we can even call ourselves friends. }\end{array}$ \\
\hline & B.M.1 & $\begin{array}{l}\text { Company climate is characterized through competition, but also } \\
\text { cooperation, friendship, teamwork. There is also an emphasis on } \\
\text { achieving company goals, but small employees are not neglected. }\end{array}$ \\
\hline & B.M.2 & $\begin{array}{l}\text { It is based on human relations, satisfying consumers and employeers } \\
\text { alike. }\end{array}$ \\
\hline
\end{tabular}

